\title{
Identification of genes specifically required for the anaerobic metabolism of benzene in Geobacter metallireducens
}

\author{
Tian Zhang ${ }^{1,2 *+}$, Pier-Luc Tremblay ${ }^{1,2+}{ }^{,}$Akhilesh K. Chaurasia ${ }^{1}$, Jessica A. Smith ${ }^{1}$, Timothy S. Bain ${ }^{1}$ \\ and Derek R. Lovley ${ }^{1}$
}

${ }^{1}$ Department of Microbiology, University of Massachusetts, Amherst, MA, USA

2 The Novo Nordisk Foundation Center for Biosustainability, Technical University of Denmark, Hørsholm, Denmark

\section{Edited by:}

John D. Coates, University of

California, Berkeley, USA

\section{Reviewed by:}

Kelly Bidle, Rider University, USA

Maria-Jose Bonete, University of

Alicante, Spain

\section{*Correspondence:}

Tian Zhang, The Novo Nordisk

Foundation Center for

Biosustainability, Technical

University of Denmark, Kogle Allé 6,

Hørsholm, DK-2970, Denmark

e-mail: zhang@biosustain.dtu.dk

these authors have contributed equally to this work.

\begin{abstract}
Although the biochemical pathways for the anaerobic degradation of many of the hydrocarbon constituents in petroleum reservoirs have been elucidated, the mechanisms for anaerobic activation of benzene, a very stable molecule, are not known. Previous studies have demonstrated that Geobacter metallireducens can anaerobically oxidize benzene to carbon dioxide with Fe(III) as the sole electron acceptor and that phenol is an intermediate in benzene oxidation. In an attempt to identify enzymes that might be involved in the conversion of benzene to phenol, whole-genome gene transcript abundance was compared in cells metabolizing benzene and cells metabolizing phenol. Eleven genes had significantly higher transcript abundance in benzene-metabolizing cells. Five of these genes had annotations suggesting that they did not encode proteins that could be involved in benzene metabolism and were not further studied. Strains were constructed in which one of the remaining six genes was deleted. The strain in which the monocistronic gene Gmet 0232 was deleted metabolized phenol, but not benzene. Transcript abundance of the adjacent monocistronic gene, Gmet 0231, predicted to encode a zinc-containing oxidoreductase, was elevated in cells metabolizing benzene, although not at a statistically significant level. However, deleting Gmet 0231 also yielded a strain that could metabolize phenol, but not benzene. Although homologs of Gmet 0231 and Gmet 0232 are found in microorganisms not known to anaerobically metabolize benzene, the adjacent localization of these genes is unique to $G$. metallireducens. The discovery of genes that are specifically required for the metabolism of benzene, but not phenol in G. metallireducens is an important step in potentially identifying the mechanisms for anaerobic benzene activation.
\end{abstract}

Keywords: benzene activation, anaerobic oxidation, phenol, Geobacter metallireducens, oxidoreductase

\section{INTRODUCTION}

Microbial degradation of the hydrocarbons in petroleum reservoirs is of interest because of its potential impact on the hydrocarbon composition and quality of deposits as well as reservoir souring (Head et al., 2010). Furthermore, anaerobic oxidation of hydrocarbons coupled to the reduction of $\mathrm{Fe}(\mathrm{III})$ minerals can have a significant influence on subsurface biogeochemistry, including the production of magnetite which can provide magnetic anomaly signals that can aid in localizing deposits (Lovley, 1991).

The availability of pure cultures capable of anaerobically degrading alkanes and substituted aromatic hydrocarbons has yielded a substantial understanding of the pathways for the degradation of these constituents of crude oil (Widdel and Rabus, 2001; Foght, 2008; Meckenstock and Mouttaki, 2011; Heider and Schühle, 2013). Due to a paucity of model pure cultures, less is known about the anaerobic degradation of benzene, a significant crude oil constituent, not only because of its value as a petrochemical/fuel component, but also because of its human toxicity (Lovley, 2000; Coates et al., 2002; Vogt et al., 2011).

Until recently, the study of anaerobic benzene degradation has been limited to investigations with mixed cultures with a focus on the ability of anaerobes to remove benzene from contaminated groundwater (Widdel and Rabus, 2001; Foght, 2008; Lovley et al., 2011; Meckenstock and Mouttaki, 2011; Heider and Schühle, 2013). Anaerobic benzene degradation has been documented under methanogenic conditions (Grbic-Galic and Vogel, 1987; Weiner and Lovley, 1998; Sakai et al., 2009; Masumoto et al., 2012) as well as with either Fe(III) (Lovley et al., 1994, 1996), sulfate (Lovley et al., 1995; Anderson and Lovley, 2000), nitrate (van der Zaan et al., 2012), or an electrode (Zhang et al., 2010) serving as the electron acceptor. In some of these mixed culture studies there was evidence that the first step in anaerobic benzene activation was conversion to phenol (Vogel and Grbicgalic, 1986; Grbic-Galic and Vogel, 1987; Weiner and Lovley, 1998; Caldwell and Suflita, 2000), whereas in other instances there was evidence that benzene was first metabolized to benzoate 
(Chaudhuri and Wiesmann, 1995; Caldwell and Suflita, 2000; Kunapuli et al., 2008; Abu Laban et al., 2010) or toluene (Ulrich et al., 2005). However, technical difficulties in working with mixed cultures have prevented definitive studies on the mechanisms for anaerobic benzene activation.

Dechloromonas aromatica grew with benzene as the sole electron donor in an anaerobic medium with nitrate as the electron acceptor (Coates et al., 2001; Chakraborty and Coates, 2005; Chakraborty et al., 2005). Phenol was proposed to be the first product of benzene activation. However, the finding that the oxygen in the phenol produced was not derived from water (Chakraborty and Coates, 2005), as well as the presence of genes for oxygen-dependent benzene metabolism coupled with a lack of genes for anaerobic metabolism of phenol or other potential aromatic intermediates (Salinero et al., 2009), suggested that molecular oxygen was involved in benzene metabolism, even though the medium was anaerobic. It has been suggested that D. aromatica utilizes molecular oxygen generated intracellularly from nitrate for benzene activation (Salinero et al., 2009; Weelink et al., 2010; Meckenstock and Mouttaki, 2011; Vogt et al., 2011), but this possibility has yet to be experimentally verified.

The hyperthermophilic archeon, Ferroglobus placidus was the first organism in pure culture unequivocally found to be capable of anaerobically oxidizing benzene (Holmes et al., 2011). F. placidus oxidizes benzene to carbon dioxide with $\mathrm{Fe}(\mathrm{III})$ as the sole electron acceptor (Holmes et al., 2011). Benzoate, but not phenol or toluene, transiently accumulated during benzene metabolism and $\left[{ }^{14} \mathrm{C}\right]$-benzoate was produced from $\left[{ }^{14} \mathrm{C}\right]$-benzene (Holmes et al., 2011). Genome-scale transcriptional analysis demonstrated that during growth on benzene, there was an increase in transcript abundance for genes specifically involved in the metabolism of benzoate, but not phenol. Transcript abundance for a putative carboxylase gene was higher during growth on benzene vs. benzoate, suggesting a potential candidate enzyme for the carboxylation reaction (Holmes et al., 2011). The lack of a genetic system for F. placidus, and the technical difficulties of working with a hyperthermophile, has limited further investigation of the benzene degradation pathway in F. placidus.

However, it has subsequently been found that Geobacter metallireducens, which can be genetically manipulated (Oberender et al., 2012; Tremblay et al., 2012; Smith et al., 2013), is also capable of anaerobically oxidizing benzene with the reduction of $\mathrm{Fe}(\mathrm{III})$ (Zhang et al., 2012, 2013). As previously reviewed (Lovley et al., 2011), Geobacter species are thought to be important agents for the removal of benzene and other aromatic hydrocarbons from a diversity of contaminated subsurface environments in which $\mathrm{Fe}(\mathrm{III})$ minerals are available. Multiple lines of evidence demonstrated that G. metallireducens metabolized benzene via a phenol intermediate rather than benzoate (Zhang et al., 2013). For example, small amounts of phenol were detected during growth on benzene and ${ }^{18} \mathrm{O}$-labeling studies demonstrated that oxygen was derived from water to generate phenol. Transcripts for genes specifically involved in the metabolism of phenol were more abundant during growth on benzene than during growth on alternative aromatic substrates, and the deletion of the genes for subunits of two enzymes involved in phenol degradation prevented the metabolism of benzene whereas deleting genes specific for benzoate or toluene metabolism had no impact on benzene metabolism.

The conversion of benzene to phenol is an exergonic reaction at $\mathrm{pH} 7$ under standard conditions:

$$
\text { Benzene }+\mathrm{H}_{2} \mathrm{O} \rightarrow \text { phenol }+2 \mathrm{H}^{+} \Delta \mathrm{G}^{0^{\prime}}=-14.7 \mathrm{~kJ} / \mathrm{mol}
$$

(calculated with data from Thauer et al., 1977)

The exergonic hydroxylation reaction of benzene by G. metallireducens is consistent with other characterized biological anaerobic hydroxylation reactions such as the conversion of ethylbenzene to (S)-1-phenylethanol and the hydration of acetylene to acetaldehyde, which are exergonic reactions performed by enzymes belonging to oxidoreductase families (Rosner and Schink, 1995; Johnson et al., 2001; Kniemeyer and Heider, 2001).

Here we report on studies designed to identify genes encoding enzymes involved in the initial activation of benzene to phenol. Target genes identified from previously published (Zhang et al., 2013) whole-genome transcriptomic analysis were deleted to ascertain genes required for the metabolism of benzene, but not phenol, that might encode candidate enzymes for benzene activation.

\section{MATERIALS AND METHODS ORGANISMS AND CULTURE CONDITIONS}

The bacterial strains and plasmids used in this study are listed in Table S1. Geobacter metallireducens (ATCC 53774 and DSM 7210) (Lovley et al., 1993) was routinely cultured under strict anaerobic conditions at $30^{\circ} \mathrm{C}$ with acetate $(10 \mathrm{mM})$ as the electron donor and $\mathrm{Fe}(\mathrm{III})$ citrate $(50 \mathrm{mM})$ as the electron acceptor, as previously described (Lovley and Phillips, 1988).

Metabolism of labeled compounds was investigated with cell suspensions as previously described (Zhang et al., 2013). Additions for $\left[{ }^{14} \mathrm{C}\right]$-labeling studies were $2.59 \times 10^{5}$ Bq of ${ }^{14} \mathrm{C}$ $\left[39 \mu \mathrm{M} \quad\left[\mathrm{UL}^{-1}{ }^{14} \mathrm{C}\right]\right.$ benzene $\left(2.78 \times 10^{9} \mathrm{~Bq} \mathrm{mmol}^{-1}\right.$; Moravek Biochemicals, Brea, CA, USA) or $1.85 \times 10^{5} \mathrm{~Bq}\left[\mathrm{U}_{-}{ }^{14} \mathrm{C}\right]$ phenol $\left(2.96 \times 10^{9} \mathrm{~Bq} \mathrm{mmol}^{-1}\right.$; ARC, St-Louis, MO, USA $\left.)\right]$.

\section{ANALYSIS OF GENE EXPRESSION}

Whole-genome microarray analysis of gene transcript abundance in cells metabolizing different aromatic substrates or acetate have previously been described (Zhang et al., 2013; NCBI GEO under accession number GSE33794). The microarray results were analyzed with Array 4 Star (DNASTAR, Madison, WI, USA).

\section{MUTANT CONSTRUCTION}

Mutants were constructed as described previously (Zhang et al., 2013). Genomic DNA was extracted with the Epicentre MasterPure DNA Purification Kit (Epicentre Biotechnologies, Madison, WI, USA). Plasmids were extracted with the QIAprep Spin Miniprep Kit (Qiagen, Valencia, CA, USA). PCR amplification was done with the Taq polymerase (Qiagen). DNA gel purification was done with the QIAquick gel extraction kit (Qiagen). Mutant alleles were constructed by replacing the coding sequences with a spectinomycin resistance. Briefly, upstream and downstream flanking regions of the genes to be deleted (ca. $500 \mathrm{bp}$ ) 
were amplified. PCR products were mixed, digested with AvrII (NEB, Beverly, MA) and ligated with the T4 DNA ligase (NEB). The resulting construct (ca. $1 \mathrm{~kb}$ ) was cloned into pCR2.1-TOPO with a TOPO TA Cloning Kit (Invitrogen, Carlsbad, CA, USA). The spectinomycin resistance cassette with AvrII sites at both ends was amplified with pRG5 (Kim et al., 2005) as a template. The spectinomycin resistance cassette was AvrII-digested and ligated into the AvrII site located between the flanking regions of the genes to be deleted. Plasmids bearing the mutant alleles were linearized by restriction enzyme digestion. The linearized plasmids were electroporated into G. metallireducens as described previously (Tremblay et al., 2012). Genotypes of the mutant strains were confirmed with PCR and the absence of undesired mutations was confirmed with Sanger sequencing.

\section{RESULTS AND DISCUSSION}

In order to identify genes that might be specifically associated with the initial conversion of benzene to phenol, gene transcript abundance was compared in cells metabolizing benzene and cells metabolizing phenol. There were 11 genes with higher transcript abundance in cells metabolizing benzene than in cells metabolizing phenol (Table 1). Each of these genes was also more highly expressed in cells metabolizing benzene than in cells metabolizing benzoate, toluene, or acetate (Table 1 ).

Five of these genes with higher transcript abundance in benzene-metabolizing cells were predicted to be involved either in flagella synthesis, in the CRISPR system, or to be a toxin or a porin (Table 1), suggesting that they are unlikely to be involved in an enzymatic attack on benzene. Therefore, the function of these genes was not further investigated. Strains in which one of the remaining six genes was deleted were constructed to determine whether the loss of the gene specifically impacted benzene metabolism.

Strains lacking either Gmet 0244, Gmet 2410, or Gmet 3229, oxidized benzene at rates just slightly lower or comparable to wild type (Figure 1), suggesting that they did not encode enzymes important in benzene metabolism. Gmet 0244 encodes a hypothetical protein, whereas Gmet 2410 and Gmet 3229 are predicted to encode a superoxide dismutase, and a thioredoxinrelated protein, respectively. The strain in which Gmet 2833 was deleted was deficient in phenol metabolism as well as benzene metabolism (Figure 2), indicating that this gene of unknown function did not have a role specific to benzene metabolism.

The strain lacking a functional Gmet 3376 oxidized benzene slightly slower and to a lesser extent than wild-type, whereas this strain metabolized phenol just as well as wild-type (Figure 2). Gmet 3376 encodes a hypothetical protein of 219 amino acids with no known homolog in any other Geobacter species. The ability of the Gmet 3376-deficient strain to continue to metabolize benzene at substantial rate suggests that it does not encode an enzyme that is required for benzene activation.

In contrast, deletion of the monocistronic gene Gmet 0232 specifically inhibited the metabolism of benzene, but not phenol (Figure 2). Gmet 0232 encodes for a hypothetical protein of 281 amino acids with homologs found only in Geobacteraceae family members and in Nitrosomonas sp. (strain Is79A3).

The transcript abundance of the adjacent gene, Gmet 0231 (Figure 3), was elevated in benzene-metabolizing cells (44.6fold compared to acetate-metabolizing cells; $P$-value $=0.00004$ ), but the difference in transcript abundance between benzeneand phenol-metabolizing cells was too low to be considered to be significantly higher in benzene-metabolizing cells (1.7-fold higher; $P$-value $=0.003$ ). Gmet 0231 is predicted to be a monocistronic gene encoding a zinc-containing oxidoreductase of the NADPH:quinone oxidoreductase family. A strain in which Gmet 0231 was deleted had a phenotype similar to the strain deficient in Gmet 0232; phenol was metabolized as well as in wild-type, but benzene metabolism was inhibited (Figure 2).

\section{IMPLICATIONS}

The results demonstrate that G. metallireducens specifically requires genes Gmet 0231 and 0232 for the metabolism of benzene, but not phenol. This raises the possibility that Gmet 0231 or Gmet 0232 , or both, encode an enzyme(s) involved in the initial

Table 1 | Genes up-regulated at least two fold in $G$. metallireducens when benzene is the electron donor ( $P$-value cutoff $\leq 0.1$; NCBI GEO under accession number GSE33794).

\begin{tabular}{|c|c|c|c|c|c|c|}
\hline \multirow[t]{2}{*}{ Gene } & \multirow[t]{2}{*}{ Annotation } & \multirow[t]{2}{*}{ Name } & \multicolumn{4}{|c|}{ Fold change: benzene vs. } \\
\hline & & & Phenol & Benzoate & Toluene & Acetate \\
\hline Gmet $0232^{a}$ & Conserved hypothetical protein & & 3 & 20.2 & 2.6 & 18.1 \\
\hline Gmet $0244^{a}$ & Conserved hypothetical protein & & 3.9 & 14 & 5 & 19.5 \\
\hline Gmet 0802 & Putative porin & & 2.4 & 9.9 & 3.5 & 14.9 \\
\hline Gmet 1065 & CRISPR-associated protein & casD & 2.3 & 13.3 & 2.6 & 13 \\
\hline Gmet $2410^{a}$ & Superoxide dismutase & sodA & 6.1 & 2.3 & 2.7 & 4.3 \\
\hline Gmet $2833^{a}$ & Conserved hypothetical protein & & 2.7 & 5.5 & 3 & 5.1 \\
\hline Gmet 3104 & Flagellar operon protein of unknown function DUF3766 & & 3.2 & 8.4 & 9 & 8 \\
\hline Gmet 3105 & flagellar hook capping protein & $f l g D$ & 2.5 & 5.9 & 7.4 & 5.4 \\
\hline Gmet 3076 & Toxin, PIN family & & 2.7 & 12.4 & 3.4 & 9.5 \\
\hline Gmet $3229^{a}$ & Thioredoxin-related protein disulfide reductase, putative & & 2.1 & 6.5 & 2.9 & 4.4 \\
\hline Gmet $3376^{a}$ & Conserved hypothetical protein & & 2.2 & 137.3 & 3.6 & 141.6 \\
\hline
\end{tabular}

${ }^{a}$ Genes studied by functional genetic. 
activation of benzene to produce phenol, or serve an important ancillary role in this phase of benzene metabolism.

Gmet 0232 homologs are found in two Geobacter species, Geobacter sulfurruducens (Caccavo et al., 1994), and Geobacter uraniireducens (Shelobolina et al., 2008), that are unable to anaerobically oxidize monoaromatic hydrocarbons. Gmet 0231 homologs are found in multiple species throughout the three kingdoms of life that are not known to degrade monoaromatic hydrocarbons, including several Geobacter species. However, the
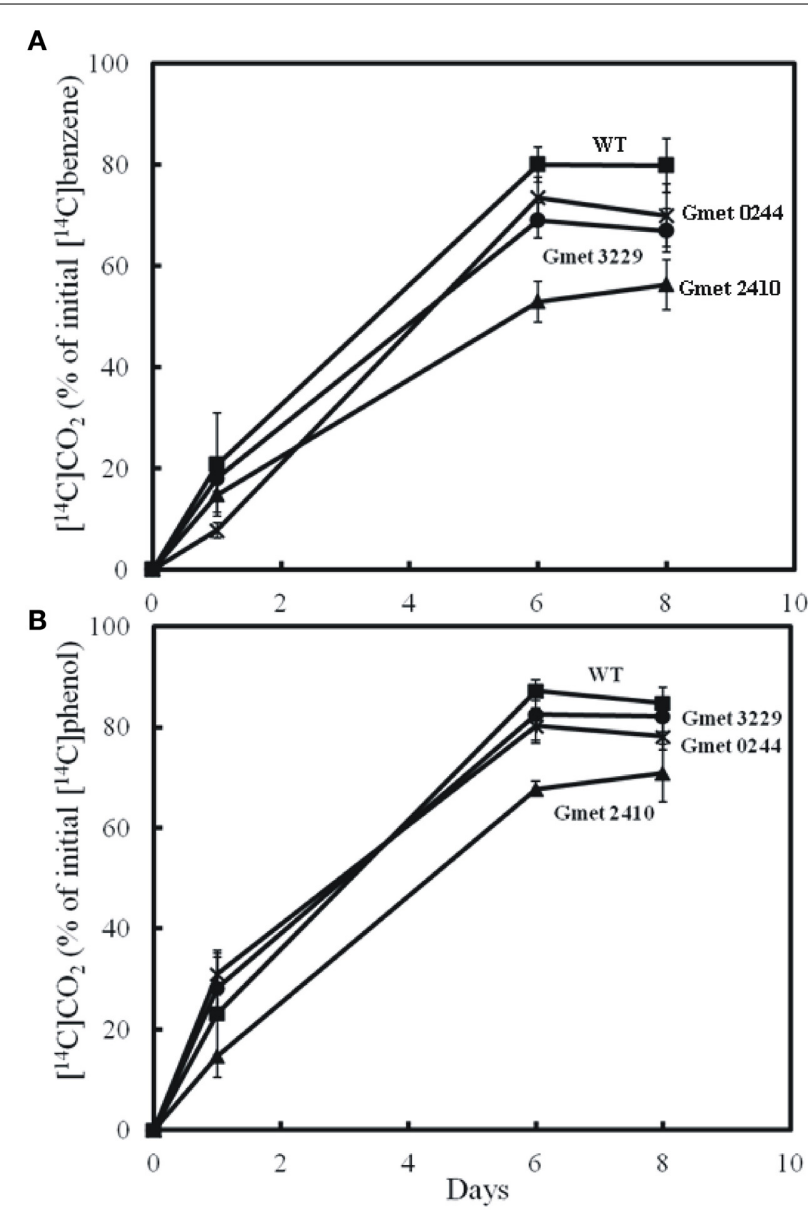

FIGURE 1 | Production of ${ }^{14} \mathrm{CO}_{2}$ by cell suspension of strains lacking Gmet 0244, Gmet 2410, or Gmet 3229 from (A) $\left[{ }^{14} \mathrm{C}\right]$ benzene or (B)

$\left[{ }^{14} \mathrm{C}\right]$ phenol. The results are the mean and standard deviation for triplicate cell suspensions. co-localization of Gmet 0231 and Gmet 0232 found in G. metallireducens has not been observed in any other microbial genome sequence, suggesting that a functional relation between the proteins encoded by Gmet 0231 and Gmet 0232 might be necessary for benzene conversion to phenol by G. metallireducens. Now that Gmet 0231 and Gmet 0232 have been identified as having an important role in the initial steps in benzene metabolism, biochemical studies of the gene products is warranted.
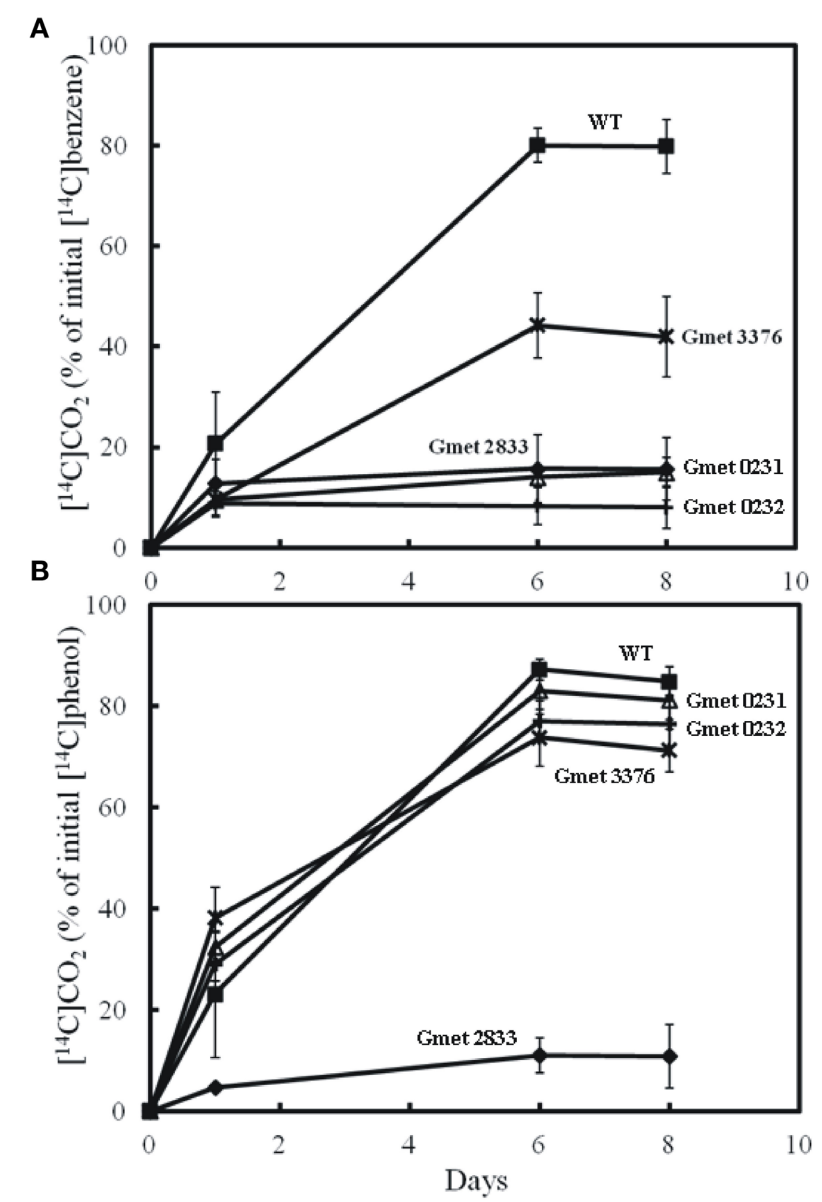

FIGURE 2 | Production of ${ }^{14} \mathrm{CO}_{2}$ by cell suspension of strains lacking Gmet 0231, Gmet 0232, Gmet 2833, or Gmet 3376 from (A)

$\left[{ }^{14} \mathrm{C}\right]$ benzene or $(\mathrm{B})\left[{ }^{14} \mathrm{C}\right]$ phenol. The results are the mean and standard deviation for triplicate cell suspensions.

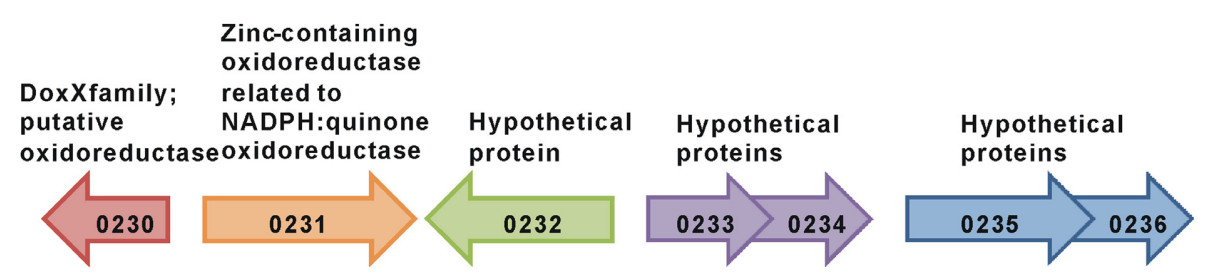

FIGURE 3 | The Gmet 0232 genomic region. 
Also warranted are studies on the function of genes localized near Gmet 0231 and Gmet 0232 in the G. metallireducens genome. For example, Gmet 0230 is predicted to encode an oxidoreductase of the DoxX family, which has sequence similarities with DoxD, a subunit of the membrane-bound thiosulphate:quinone oxidoreductase (Muller et al., 2004). Genes adjacent to Gmet 0232 are predicted to encode hypothetical proteins of unknown function (Figure 3), suggesting that genetic analysis of their function in benzene metabolism may also be warranted.

It has been suggested (Coates et al., 2002) that enzymes with functions similar to the ethylbenzene dehydrogenase found in Aromataleum aromaticum (Johnson and Spormann, 1999; Kniemeyer and Heider, 2001) or the acetylene hydratase of Pelobacter acetylinus (Schink, 1985; Rosner and Schink, 1995) might be involved in the anaerobic hydroxylation of benzene. None of the genes investigated here have any homology to the components of either of those enzyme complexes. Thus, these results suggest that $G$. metallireducens may possess a novel biochemistry for the anaerobic hydroxylation of benzene.

\section{ACKNOWLEDGMENT}

This research was supported by grant N00014-13-1-0550 from the Office of Naval Research.

\section{SUPPLEMENTARY MATERIAL}

The Supplementary Material for this article can be found online at: http://www.frontiersin.org/journal/10.3389/fmicb.2014. 00245/abstract

\section{Table S1 | Bacterial strains and plasmids used in this study.}

\section{REFERENCES}

Abu Laban, N., Selesi, D., Rattei, T., Tischler, P., and Meckenstock, R. U. (2010). Identification of enzymes involved in anaerobic benzene degradation by a strictly anaerobic iron-reducing enrichment culture. Environ. Microbiol. 12, 2783-2796. doi: 10.1111/j.1462-2920.2010.02248.x

Anderson, R. T., and Lovley, D. R. (2000). Anaerobic bioremediation of benzene under sulfate-reducing conditions in a petroleum-contaminated aquifer. Environ. Sci. Technol. 34, 2261-2266. doi: 10.1021/es991211a

Caccavo, F. Jr., Lonergan, D. J., Lovley, D. R., Davis, M., Stolz, J. F., and McInerney, M. J. (1994). Geobacter sulfurreducens sp. nov., a hydrogen- and acetate-oxidizing dissimilatory metal-reducing microorganism. Appl. Environ. Microbiol. 60, 3752-3759.

Caldwell, M. E., and Suflita, J. M. (2000). Detection of phenol and benzoate as intermediates of anaerobic benzene biodegradation under different terminal electron-accepting conditions. Environ. Sci. Technol. 34, 1216-1220. doi: $10.1021 /$ es $990849 j$

Chakraborty, R., and Coates, J. D. (2005). Hydroxylation and carboxylationtwo crucial steps of anaerobic benzene degradation by Dechloromonas strain RCB. Appl. Environ. Microbiol. 71, 5427-5432. doi: 10.1128/AEM.71.9.54275432.2005

Chakraborty, R., O'Connor, S. M., Chan, E., and Coates, J. D. (2005). Anaerobic degradation of benzene, toluene, ethylbenzene, and xylene compounds by Dechloromonas strain RCB. Appl. Environ. Microbiol. 71, 8649-8655. doi: 10.1128/AEM.71.12.8649-8655.2005

Chaudhuri, B. K., and Wiesmann, U. (1995). Enhanced anaerobic degradation of benzene by enrichment of mixed microbial culture and optimization of the culture medium. Appl. Microbiol. Biotechnol. 43, 178-187. doi: 10.1007/BF00170641

Coates, J. D., Chakraborty, R., Lack, J. G., O’Connor, S. M., Cole, K. A., Bender, K. S., et al. (2001). Anaerobic benzene oxidation coupled to nitrate reduction in pure culture by two strains of Dechloromonas. Nature 411, 1039-1043. doi: $10.1038 / 35082545$
Coates, J. D., Chakraborty, R., and McInerney, M. J. (2002). Anaerobic benzene biodegradation-a new era. Res. Microbiol. 153, 621-628. doi: 10.1016/S09232508(02)01378-5

Foght, J. (2008). Anaerobic biodegradation of aromatic hydrocarbons: pathways and prospects. J. Mol. Microbiol. Biotechnol. 15, 93-120. doi: 10.1159/000121324

Grbic-Galic, D., and Vogel, T. M. (1987). Transformation of toluene and benzene by mixed methanogenic cultures. Appl. Environ. Microbiol. 53, 254-260.

Head, I. M., Larter, S. R., Gray, N. D., Sherry, A., Adams, J. J., Aitken, C. M., et al. (2010). "Hydrocarbon degradation in petroleum reservoirs," in Handbook of Hydrocarbon and Lipid Microbiology, Vol. 4, eds K. N. Timmis, T. McGenity, J. R. van der Meer, and V. de Lorenzo (Heidelberg; Germany: Springer), 3097-3109.

Heider, J., and Schühle, K. (2013). "Anaerobic biodegradation of hydrocarbons including methane," in The Prokaryotes, eds E. Rosenberg, E. F. Delong, S. Lory, E. Stackebrandt, and F. Thompson (Berlin; Heidelberg: Springer-Verlag), 605-634. doi: 10.1007/978-3-642-30141-4_80

Holmes, D. E., Risso, C., Smith, J. A., and Lovley, D. R. (2011). Anaerobic oxidation of benzene by the hyperthermophilic archaeon Ferroglobus placidus. Appl. Environ. Microbiol. 77, 5926-5933. doi: 10.1128/AEM.05 452-11

Johnson, H. A., Pelletier, D. A., and Spormann, A. M. (2001). Isolation and characterization of anaerobic ethylbenzene dehydrogenase, a novel Mo-Fe-S enzyme. J. Bacteriol. 183, 4536-4542. doi: 10.1128/JB.183.15.4536-4542.2001

Johnson, H. A., and Spormann, A. M. (1999). In vitro studies on the initial reactions of anaerobic ethylbenzene mineralization. J. Bacteriol. 181, 5662-5668.

Kim, B. C., Leang, C., Ding, Y. H., Glaven, R. H., Coppi, M. V., and Lovley, D. R. (2005). OmcF, a putative c-type monoheme outer membrane cytochrome required for the expression of other outer membrane cytochromes in Geobacter sulfurreducens. J. Bacteriol. 187, 4505-4513. doi: 10.1128/JB.187.13.45054513.2005

Kniemeyer, O., and Heider, J. (2001). Ethylbenzene dehydrogenase, a novel hydrocarbon-oxidizing molybdenum/iron-sulfur/heme enzyme. J. Biol. Chem. 276, 21381-21386. doi: 10.1074/jbc.M101679200

Kunapuli, U., Griebler, C., Beller, H. R., and Meckenstock, R. U. (2008). Identification of intermediates formed during anaerobic benzene degradation by an iron-reducing enrichment culture. Environ. Microbiol. 10, 1703-1712. doi: 10.1111/j.1462-2920.2008.01588.x

Lovley, D. R. (1991). Dissimilatory Fe(III) and Mn(IV) reduction. Microbiol. Rev. 55, 259-287.

Lovley, D. R. (2000). Anaerobic benzene degradation. Biodegradation 11, 107-116. doi: 10.1023/A:1011191220463

Lovley, D. R., Coates, J. D., Woodward, J. C., and Phillips, E. (1995). Benzene oxidation coupled to sulfate reduction. Appl. Environ. Microbiol. 61, 953-958.

Lovley, D. R., Giovannoni, S. J., White, D. C., Champine, J. E., Phillips, E. J. P., Gorby, Y. A., et al. (1993). Geobacter metallireducens gen. nov. sp. nov., a microorganism capable of coupling the complete oxidation of organic compounds to the reduction of iron and other metals. Arch. Microbiol. 159, 336-344. doi: $10.1007 / \mathrm{BF} 00290916$

Lovley, D. R., and Phillips, E. J. (1988). Novel mode of microbial energy metabolism: organic carbon oxidation coupled to dissimilatory reduction of iron or manganese. Appl. Environ. Microbiol. 54, 1472-1480.

Lovley, D. R., Ueki, T., Zhang, T., Malvankar, N. S., Shrestha, P. M., Flanagan, K., et al. (2011). Geobacter: the microbe electric's physiology, ecology, and practical applications. Adv. Microb. Physiol. 59, 1-100. doi: 10.1016/B978-0-12-3876614.00004-5

Lovley, D. R., Woodward, J. C., and Chapelle, F. H. (1994). Stimulated anoxic biodegradation of aromatic hydrocarbons using Fe(III) ligands. Nature 370, 128-131. doi: 10.1038/370128a0

Lovley, D. R., Woodward, J. C., and Chapelle, F. H. (1996). Rapid anaerobic benzene oxidation with a variety of chelated Fe(III) forms. Appl. Environ. Microbiol. 62, 288-291.

Masumoto, H., Kurisu, F., Kasuga, I., Tourlousse, D. M., and Furumai, H. (2012). Complete mineralization of benzene by a methanogenic enrichment culture and effect of putative metabolites on the degradation. Chemosphere 86, 822-888. doi: 10.1016/j.chemosphere.2011.11.051

Meckenstock, R. U., and Mouttaki, H. (2011). Anaerobic degradation of nonsubstituted aromatic hydrocarbons. Curr. Opin. Biotechnol. 22, 406-414. doi: 10.1016/j.copbio.2011.02.009

Muller, F. H., Bandeiras, T. M., Urich, T., Teixeira, M., Gomes, C. M., and Kletzin, A. (2004). Coupling of the pathway of sulphur oxidation to dioxygen reduction: 
characterization of a novel membrane-bound thiosulphate:quinone oxidoreductase. Mol. Microbiol. 53, 1147-1160. doi: 10.1111/j.1365-2958.2004.04193.x

Oberender, J., Kung, J. W., Seifert, J., von Bergen, M., and Boll, M. (2012). Identification and characterization of a succinyl-coenzyme A (CoA):benzoate CoA transferase in Geobacter metallireducens. J. Bacteriol. 194, 2501-2508. doi: 10.1128/JB.00306-12

Rosner, B. M., and Schink, B. (1995). Purification and characterization of acetylene hydratase of Pelobacter acetylenicus, a tungsten iron-sulfur protein. J. Bacteriol. 177, 5767-5772.

Sakai, N., Kurisu, F., Yagi, O., Nakajima, F., and Yamamoto, K. (2009). Identification of putative benzene-degrading bacteria in methanogenic enrichment cultures. J. Biosci. Bioeng. 108, 501-507. doi: 10.1016/j.jbiosc.2009.06.005

Salinero, K. K., Keller, K., Feil, W. S., Feil, H., Trong, S., di Bartolo, G., et al. (2009). Metabolic analysis of the soil microbe Dechloromonas aromatica str. RCB: indications of a surprisingly complex life-style and cryptic anaerobic pathways for aromatic degradation. BMC Genomics 10:351. doi: 10.1186/1471-2164-10-351

Schink, B. (1985). Fermentation of acetylene by an obligate anaerobe, Pelobacter acetylenicus sp. nov. Arch. Microbiol. 142, 295-301. doi: 10.1007/BF00693407

Shelobolina, E. S., Vrionis, H. A., Findlay, R. H., and Lovley, D. R. (2008). Geobacter uraniireducens sp. nov., isolated from subsurface sediment undergoing uranium bioremediation. Int. J. Syst. Evol. Microbiol. 58, 1075-1078. doi: 10.1099/ijs.0.65377-0

Smith, J. A., Lovley, D. R., and Tremblay, P. L. (2013). Outer cell surface components essential for Fe(III) oxide reduction by Geobacter metallireducens. Appl. Environ. Microbiol. 79, 901-907. doi: 10.1128/AEM.02954-12

Thauer, R. K., Jungermann, K., and Decker, K. (1977). Energy conservation in chemotrophic anaerobic bacteria. Bacteriol. Rev. 41, 100-180.

Tremblay, P. L., Aklujkar, M., Leang, C., Nevin, K. P., and Lovley, D. (2012) A genetic system for Geobacter metallireducens: role of the flagellin and pilin in the reduction of $\mathrm{Fe}(\mathrm{III})$ oxide. Environ. Microbiol. Rep. 4, 82-88. doi: 10.1111/j.1758-2229.2011.00305.x

Ulrich, A. C., Beller, H. R., and Edwards, E. A. (2005). Metabolites detected during biodegradation of ${ }^{13} \mathrm{C}_{6}$-benzene in nitrate-reducing and methanogenic enrichment cultures. Environ. Sci. Technol. 39, 6681-6691. doi: 10.1021/es050294u

van der Zaan, B. M., Saia, F. T., Stams, A. J., Plugge, C. M., de Vos, W. M., Smidt, H., et al. (2012). Anaerobic benzene degradation under denitrifying conditions: peptococcaceae as dominant benzene degraders and evidence for a syntrophic process. Environ. Microbiol. 14, 1171-1181. doi: 10.1111/j.14622920.2012.02697.x

Vogel, T. M., and Grbicgalic, D. (1986). Incorporation of oxygen from water into toluene and benzene during anaerobic fermentative transformation. Appl. Environ. Microbiol. 52, 200-202.
Vogt, C., Kleinsteuber, S., and Richnow, H. H. (2011). Anaerobic benzene degradation by bacteria. Microb. Biotechnol. 4, 710-724. doi: 10.1111/j.17517915.2011.00260.x

Weelink, S. A. B., van Eekert, M. H. A., and Stams, A. J. M. (2010). Degradation of BTEX by anaerobic bacteria: physiology and application. Rev. Environ. Sci. Biotechnol. 9, 359-385. doi: 10.1007/s11157-010-9219-2

Weiner, J. M., and Lovley, D. R. (1998). Rapid benzene degradation in methanogenic sediments from a petroleum-contaminated aquifer. Appl. Environ. Microbiol. 64, 1937-1939.

Widdel, F., and Rabus, R. (2001). Anaerobic biodegradation of saturated and aromatic hydrocarbons. Curr. Opin. Biotechnol. 12, 259-276. doi: 10.1016/S09581669(00)00209-3

Zhang, T., Bain, T. S., Nevin, K. P., Barlett, M. A., and Lovley, D. R. (2012). Anaerobic benzene oxidation by Geobacter species. Appl. Environ. Microbiol. 78, 8304-8310. doi: 10.1128/AEM.02469-12

Zhang, T., Gannon, S. M., Nevin, K. P., Franks, A. E., and Lovley, D. R. (2010). Stimulating the anaerobic degradation of aromatic hydrocarbons in contaminated sediments by providing an electrode as the electron acceptor. Environ. Microbiol. 12, 1011-1020. doi: 10.1111/j.1462-2920.2009. 02145.x

Zhang, T., Tremblay, P. L., Chaurasia, A. K., Smith, J. A., Bain, T. S., and Lovley, D. R. (2013). Anaerobic benzene oxidation via phenol in Geobacter metallireducens. Appl. Environ. Microbiol. 79, 7800-7806. doi: 10.1128/AEM.03134-13

Conflict of Interest Statement: The authors declare that the research was conducted in the absence of any commercial or financial relationships that could be construed as a potential conflict of interest.

Received: 11 March 2014; accepted: 05 May 2014; published online: 22 May 2014 Citation: Zhang T, Tremblay P-L, Chaurasia AK, Smith JA, Bain TS and Lovley DR (2014) Identification of genes specifically required for the anaerobic metabolism of benzene in Geobacter metallireducens. Front. Microbiol. 5:245. doi: 10.3389/fmicb. 2014.00245

This article was submitted to Microbial Physiology and Metabolism, a section of the journal Frontiers in Microbiology.

Copyright (c) 2014 Zhang, Tremblay, Chaurasia, Smith, Bain and Lovley. This is an open-access article distributed under the terms of the Creative Commons Attribution License (CC BY). The use, distribution or reproduction in other forums is permitted, provided the original author(s) or licensor are credited and that the original publication in this journal is cited, in accordance with accepted academic practice. No use, distribution or reproduction is permitted which does not comply with these terms. 